\title{
Influence of mixing layer height upon air pollution in urban and sub-urban areas
}

\author{
Klaus Schäfer* , Stefan Emeis, Herbert Hoffmann and Carsten Jahn
}

Institute for Meteorology and Climate Research, Atmospheric Environmental Research, Forschungszentrum Karlsruhe GmbH (IMK-IFU), Garmisch-Partenkirchen, Germany

(Manuscript received October 31, 2005; in revised form June 30, 2006; accepted August 16, 2006)

\begin{abstract}
The mixing layer height is an important parameter characterising the potential of the atmospheric boundary layer to take up emitted air pollutants. During continuous measurements in Hanover, Germany, from 2001 until 2003 and around Munich, Germany, in summer and winter 2003 mixing layer heights (MLH) were determined by different remote sensing systems mainly from the thermal structure and turbulence of the air (SODAR), for some time from the aerosol layering of the air (ceilometer), and for a short period directly from the temperature profile (RASS). The temporal variations of the concentrations of $\mathrm{PM}_{10}$ and $\mathrm{PM}_{2.5}$ as well as of $\mathrm{CO}$ and $\mathrm{NO}_{x}$ simultaneously measured near the surface were investigated and correlated with the MLH derived from SODAR data. The pollution measurements were performed inside a street canyon and at an urban background station close to Hanover and at three measurement locations inside and outside of Munich complementing the available monitoring networks. The analyses show that the correlations of pollutant concentrations with MLH are smallest inside street canyons. Correlations at the urban background stations are larger in winter than in summer, and they are larger for the urban stations than for the rural stations. It turns out further that the correlation of $\mathrm{NO}_{x}$ concentrations with MLH is larger than the correlation of particles concentrations. Explanations for these findings must consider the varying emission source strengths for $\mathrm{NO}_{x}$ and particles and the influence of gas-to-particle conversion within air masses especially during daytime in summer.
\end{abstract}

\begin{abstract}
Zusammenfassung
Die Mischungsschichthöhe ist ein wesentlicher Parameter, der die Aufnahmefähigkeit der atmosphärischen Grenzschicht für bodennah emittierte Luftschadstoffe charakterisiert. Bei kontinuierlichen Messungen in Hannover in den Jahren 2001 bis 2003 und im Raum München im Frühsommer und Winter 2003 wurden Mischungsschichthöhen (MLH) mit unterschiedlichen Fernmessverfahren detektiert, hauptsächlich mit SODAR aus der thermischen und dynamischen Struktur der Atmosphäre, zeitgleich mit einem Ceilometer aus dem Partikelgehalt und für eine kurze Zeitspanne mit einem RASS direkt aus dem Temperaturprofil. Die gemessenen $\mathrm{NO}_{x}$ - und Partikelkonzentrationen wurden analysiert und mit der aus den SODAR-Daten bestimmten MLH korreliert. Die Schadstoffmessungen fanden in einer Straßenschlucht und einer nahe gelegenen städtischen Hintergrundstation in Hannover sowie an drei Messpositionen innerhalb und außerhalb von München statt, womit die bestehenden Messnetze ergänzt wurden. Die Analysen zeigen, dass die Korrelationen der Schadstoffkonzentrationen mit der MLH innerhalb der Straßenschlucht am geringsten sind. Generell sind die Korrelationen im Winter höher als im Sommer, in den Städten höher als im Umland, und für $\mathrm{NO}_{x}$ höher als für Partikelkonzentrationen. Erklärungen hierfür müssen die verschiedenen Emissionsquellstärken der Schadstoffe und den Einfluss der Gas-zu-Partikel-Umwandlungsprozesse innerhalb einer Luftmasse insbesondere tagsüber im Sommer berücksichtigen.
\end{abstract}

\section{Introduction}

The mixing layer height (MLH) is assumed to be a key parameter for the characterisation of air pollution together with urban emission source strengths, traffic emissions, further meteorological influences such as wind, and long-range transport and deposition. The determination and modelling of the MLH has therefore found considerable interest in the recent decade (BEYRICH, 1997; SEIBERT et al., 2000; RAMPANELli

\footnotetext{
${ }^{*}$ Corresponding author: Klaus Schäfer, Institute for Meteorology and Climate Research, Atmospheric Environmental Research, Forschungszentrum Karlsruhe $\mathrm{GmbH}$ (IMK-IFU), Kreuzeckbahnstr. 19, 82467 Garmisch-Partenkirchen, Germany, e-mail: klaus.schaefer@imk.fzk.de
}

and ZARDI, 2004; PIRINGER et al., 2005). MLH defines the volume for the dilution of air pollutants emitted or formed near the surface and thus the near-surface pollutant concentrations. In earlier studies, it was partly found that the correlation between air pollution and MLH is inconsistent (ARON, 1983). At that time MLH was available from radiosonde taken once or twice daily only. Those data gave no reliable information on the daily mean MLH and the diurnal variation of MLH. With today's availability of remote sensing devices for monitoring the structure of the atmospheric boundary layer and the MLH a re-investigation of this correlation is meaningful. Studies (e.g. SCHÄFER et al., 2002) have shown that the atmospheric boundary layer sometimes exhibits 


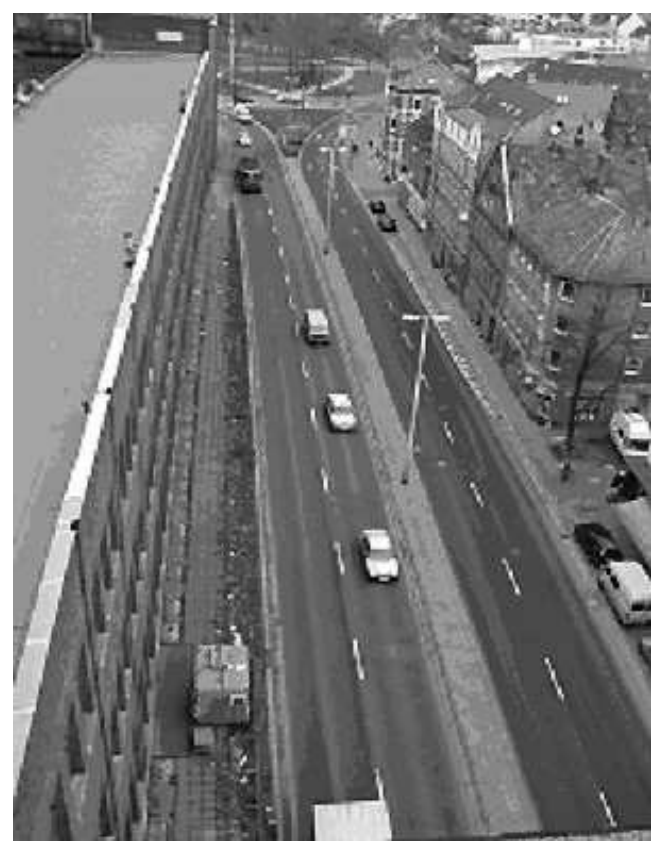

Figure 1: Göttinger Strasse in Hanover with location of three in situ measurement systems inside the street canyon (container). The rooftop station is near the position of the photographer.

multiple layering (e.g. internal boundary layers, nearsurface inversions and residual layers at night-time and in the morning hours). But it is assumed that the lowest stable layer or inversion limits the vertical exchange of primary pollutants emitted at or near the surface. Because ozone is not a primary pollutant and it is mixed into the mixing layer from above, the relationship between the MLH and the ozone concentration is an anticorrelation (ZHANG and RAO, 1999).

MLH information is also necessary for special kinds of satellite data interpretation, e. g. satellite images can provide particle concentrations by retrievals of optical depths (SPOT, Landsat) in an area of approx. $100 \mathrm{~km} \mathrm{x}$ $100 \mathrm{~km}$ (S ARIGIANNIS et al., 2002). The optical thickness of the satellite images can be likewise interpreted as the particle concentration near the surface (DANDOU et al., 2002) if MLH is known.

Two recent research projects offered the opportunity to make simultaneous measurements of near-surface air pollution by in situ measurements and of MLH by surface-based remote sensing techniques in urban areas. One experiment took place from 2001 until 2003 inside a street canyon (Göttinger Strasse in Hanover, Germany) and in the surrounding area. These investigations were designed for model validation purposes because new modelling tools such as the meso/micro-scale model system M-SYS (see TRUKENMÜLLER et al., 2004) had been developed for the execution of the European Air Quality Framework Directive 96/62/EC and its daughter directives. These directives require 12-monthly air pollution maps with a spatial resolution of $200 \mathrm{~m}^{2}$ in so-called micro-environments of high emitting air pollutant sources. Air quality monitoring data from present measurement networks in urban and sub-urban areas are inappropriate for this task because the decision for the layout of these networks did not consider the task of model validation. The second experiment was executed in summer and winter 2003 in and around Munich in order to evaluate particle concentrations retrieved from satellite information. Similar investigations, which will not be used in this study, were performed in Budapest in summer 2003 and in winter 2003/2004.

Here, the influences of MLH upon primary nearsurface air pollutant concentrations will be discussed in the following. After a description of the in situ and remote sensing measurements in both experiments the correlation between both gaseous as well as aerosol concentrations and MLH will be discussed. The investigation will focus on differences between summer and winter pollution episodes and on differences between street canyons as well as larger urban, sub-urban and rural areas.

\section{Methodology}

\subsection{Measurements}

\subsubsection{Experiments in Hanover}

The measurements in Hanover have been made from October 2001 to April 2003. Meteorological parameters (wind vector, temperature, pressure, humidity, solar radiation and those necessary for the determination of MLH, see section 2.2 below) have been measured continuously by in situ instruments (including an ultra-sonic anemometer) and by sounding techniques (SODAR (DSD3x7 mono-static Doppler SODAR) and RASS (also called WTR, Wind-Temperature-RADAR) from Metek) and a mini lidar (ceilometer CT25K from Vaisala)) south-west of Göttinger Strasse in about $500 \mathrm{~m}$ and $200 \mathrm{~m}$ distance. Air pollutants have been measured by in situ instruments (CO by a TE48, $\mathrm{NO}_{x}$ by TE42 and ML8841, PM 10 by FH62 I-R FAG Kugelfischer) and remote sensing instruments $\left(\mathrm{CO}, \mathrm{CH}_{4}, \mathrm{~N}_{2} \mathrm{O}\right.$, and $\mathrm{CO}_{2}$ by FTIR with $\mathrm{K} 300$ from Kayser-Threde) at both side walks inside the street canyon. $\mathrm{NO}, \mathrm{NO}_{2}$, and $\mathrm{O}_{3}$ are also measured by DOAS from Opsis at a side walk of this street and at the roof of the building along the western edge of this street. These sites complemented the existing monitoring network in the city of Hanover ( $\mathrm{CO}$ by a TE48, $\mathrm{NO}_{x}$ by a TE42, $\mathrm{PM}_{10}$ and $\mathrm{PM}_{2.5}$ by FH62 I-N) (see MÜLLER et al., 2001) operated by the Lower Saxony State Agency for Ecology which includes a roof-top station, too (near the position where the picture for Figure 1 was taken). The data are available in the data bank 

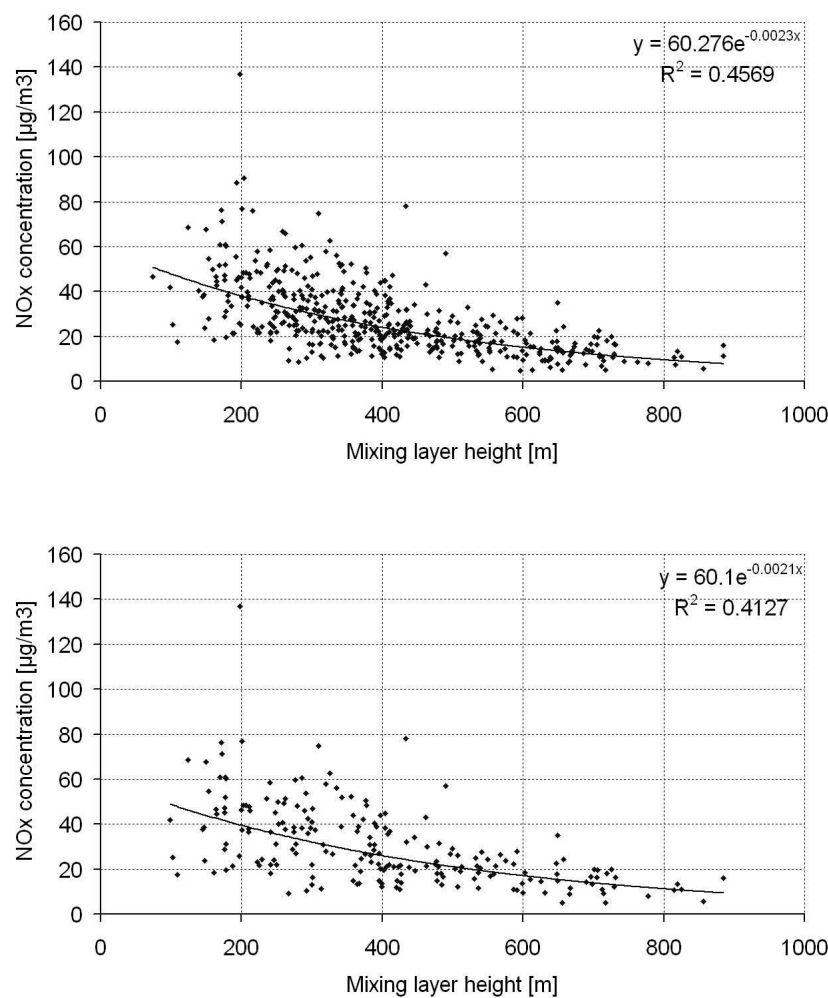

ValiData (NoLTE et al., 2004). The street canyon depthwidth relation is about one. It is nearly north-south oriented. At the west side of the street there is a closed front of buildings, and at the east side the front of buildings is interrupted by some small streets giving a typical street canyon (see Figure 1). Traffic in the Göttinger Strasse amounts to more than 30,000 cars per day.

Quality assurance and quality control included longterm comparison of all measurement techniques. Before or after each IOP the different measurement techniques were operated simultaneously in the same air mass during a time period of 36 hours (ISO 13752 Air quality). The comparisons showed deviations in the order of the measurement accuracy (SCHÄFER et al., 2005).

\subsubsection{Experiments in and around Munich}

From 10 until 29 May and from 27 November until 19 December 2003 two measurement campaigns in and around Munich at three measurement locations were performed. Some stations from the monitoring network of the Bavarian State Agency for Environmental Protection are located in this area gathering the pollution at vulnerable sites and the concentration of measured components in the surrounding area. The data of the following monitoring stations are used in this study: urban stations: Stachus (L8.1): at the side walk of a wide street canyon, 8 lanes at the street, 43,000 vehicles per day; Lothstrasse (L8.3): at the corner of a wide street, sixlane street, 41,000 vehicles per day; Moosach (L8.7): at

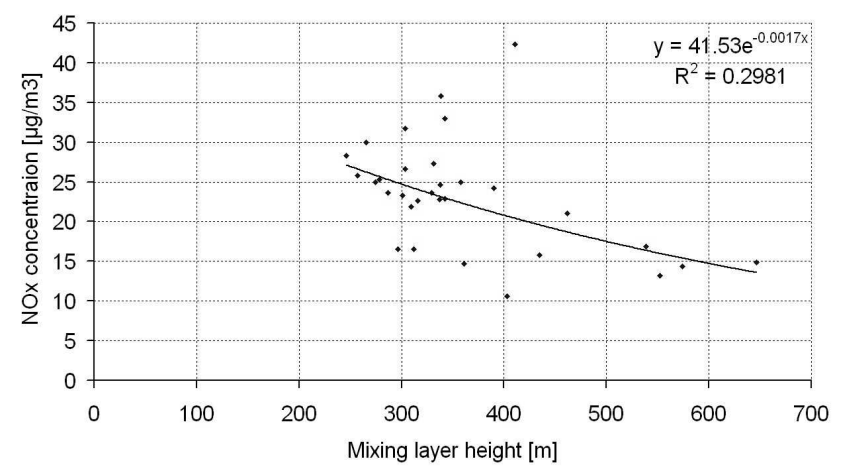

Figure 2: Seasonal variation of the square of the correlation coefficient $\mathrm{R}^{2}$ and parameters of exponential relationship for $\mathrm{NO}_{x}$ concentration with mixing layer height (MLH) from SODAR for the roof-top station at the street canyon Göttinger Strasse in Hanover (urban background): all data (top left), summer (top right) and winter (bottom).

the corner of a wide street, six-lane street, 29,000 vehicles per day; Luise-Kiesselbach-Platz (L8.11): large cross section of an access highway and the main city circle of Munich with some smaller streets, six-lane street, 117,000 vehicles per day; urban background station: Johanneskirchen (L8.12): at a small street, no large streets nearby, power plant in $1 \mathrm{~km}$ distance. Only at the stations L8.11, L8.1, L8.3 PM $_{10}$ (instrument FH62 I-N FAG Kugelfischer, three-hourly mean data) is measured. The meteorological data (wind speed and direction) are determined near the station L8.3 in $32 \mathrm{~m}$ altitude on the roof of a building. Additional air quality measurement sites inside and around Munich during the two campaigns complemented the abovementioned monitoring network and thus gave the possibility to study the background and rural air pollution in the region of Munich. Two additional air pollution measurement sites were located upwind and downwind of the city to record the rural conditions around Munich and one urban background station was setup on a roof-top in the city centre. The rural sites were: Maisach (west of Munich: $\mathrm{CO}$ by a TE48, $\mathrm{NO}_{x}$ by a ML8841, $\mathrm{PM}_{10} / \mathrm{PM}_{2.5} / \mathrm{PM}_{1}$ by SEQ47/50 Leckel) and Erding/Frankendorf (east of Munich: CO by FTIR (K300 from Kayser-Threde), PM $_{10} /$ $\mathrm{PM}_{2.5} / \mathrm{PM}_{1}$ by SEQ47/50 Leckel, ceilometer (LD40 from Vaisala)). The additional urban background station was located on the roof of the building of the MIM - Meteorological Institute of the University of Munich (DOAS from Opsis for $\mathrm{NO}, \mathrm{NO}_{2}$ and $\mathrm{O}_{3}, \mathrm{PM}_{10} / \mathrm{PM}_{2.5} /$ 

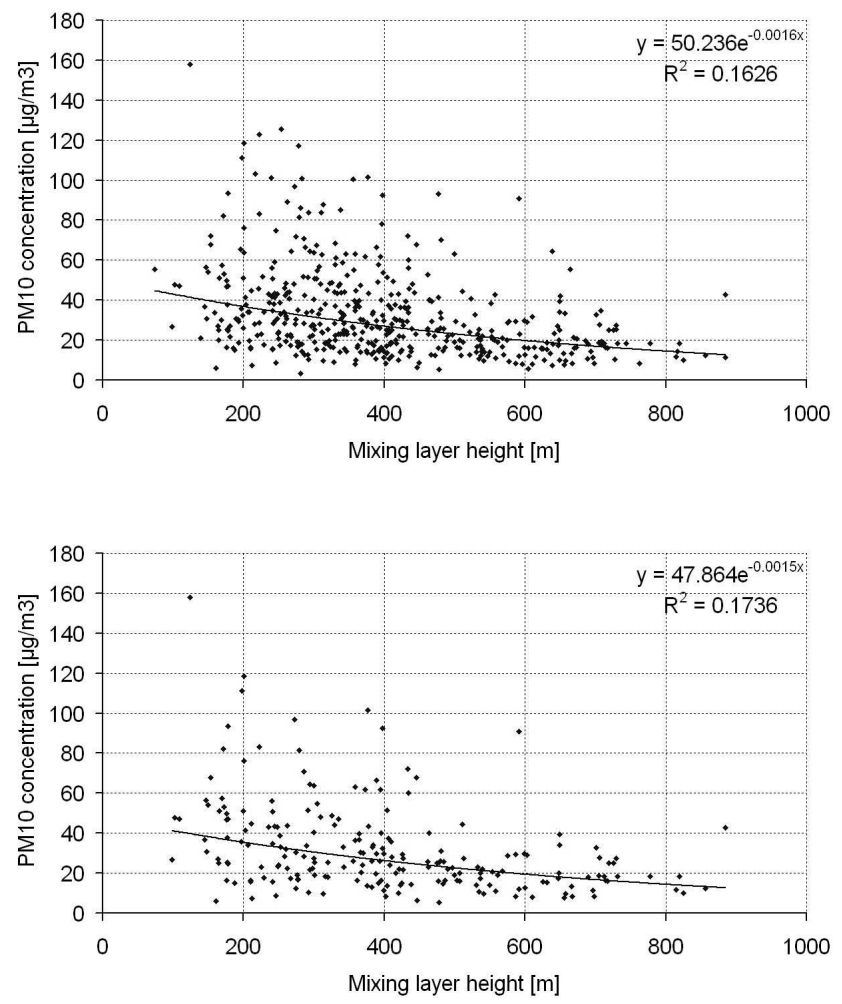

$\mathrm{PM}_{1}$ by SEQ47/50 Leckel). The SODAR was operated on Fuerstenfeldbruck airfield (close to Maisach), the ceilometer at Erding/Frankendorf, and the WTR near Erding/Lohkirchen. Meteorological parameters were determined from conventional weather stations at Maisach, MIM and Erding/Frankendorf.

Quality assurance and quality control of all instruments was made by inter-comparison against each other before or after the measurement campaigns at the urban background station of the measurement network in $\mathrm{Mu}$ nich (L8.12 Johanneskirchen) which is not influenced by significant emission sources and therefore it can be assumed that the ambient air is well mixed at this location.

\subsection{Continuous determination of MLH}

The basic principles for the determination of MLH solely from SODAR data are described in BEYRICH (1997) and in EMEIS and TÜRK (2004). This procedure can be enhanced if SODAR and ceilometer data are available simultaneously (EMEIS and SCHÄFER, 2006) or even if a RASS (WTR) is available. The three remote sensing devices SODAR, WTR, and ceilometer detect different signatures of the atmospheric layering. The SODAR discerns strong vertical thermal gradients and temperature fluctuations connected to turbulence. The ceilometer working as a mini lidar catches information on particles floating in the air which are quantified by backscatter ratio profiles (STEYN et al., 1999), and the RASS provides via the determination of the speed of

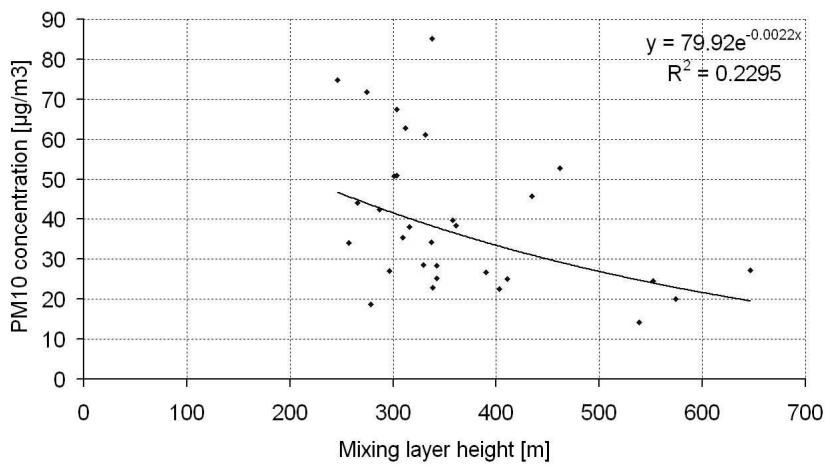

Figure 3: Seasonal variation of the square of the correlation coefficient $\mathrm{R}^{2}$ and parameters of exponential relationship for $\mathrm{PM}_{10}$ concentration with mixing layer height (MLH) from SODAR for the roof-top station at the street canyon Göttinger Strasse in Hanover (urban background): all data (top left), summer (top right) and winter (bottom).

sound a nearly direct measurement of the vertical temperature profile up to about $1000 \mathrm{~m}$ above ground.

In the present study MLH was determined solely from SODAR data as the minimum of the height of the ground-based echo layer and the height of an elevated echo maximum (if present). If the MLH was higher than the instrument's range it could not be determined from SODAR data and the MLH was set at this range. These problems caused an ambiguity of MLH parameters if the MLH is large. Details on the determination and statistical evaluations of the resulting MLH are reported in EMEIS and TÜRK (2004).

In Hanover, acoustic remote sensing of wind and turbulence profiles with vertical resolution of $12.5 \mathrm{~m}$ in the altitude range up to $600 \mathrm{~m}$ and $25 \mathrm{~m}$ in the altitude range between 600 and $1200 \mathrm{~m}$ were performed using the SODAR. Temporal averaging over 30 minutes was used before storing the data. In Hanover, WTR data were available for a few weeks only. The ceilometer was operated for several months. An intercomparison between these three remote sensing techniques is given in EMEIS et al. (2004).

At the Fuerstenfeldbruck military airfield the SODAR observations were made with a vertical resolution of $30 \mathrm{~m}$ from 55 to $1285 \mathrm{~m}$ above ground storing $10 \mathrm{~min}$ averages. The WTR and the ceilometer were operated near Erding about $50 \mathrm{~km}$ away from Fuerstenfeldbruck. During May 2003 the height range of the SODAR was not always sufficient to detect the MLH during the af- 

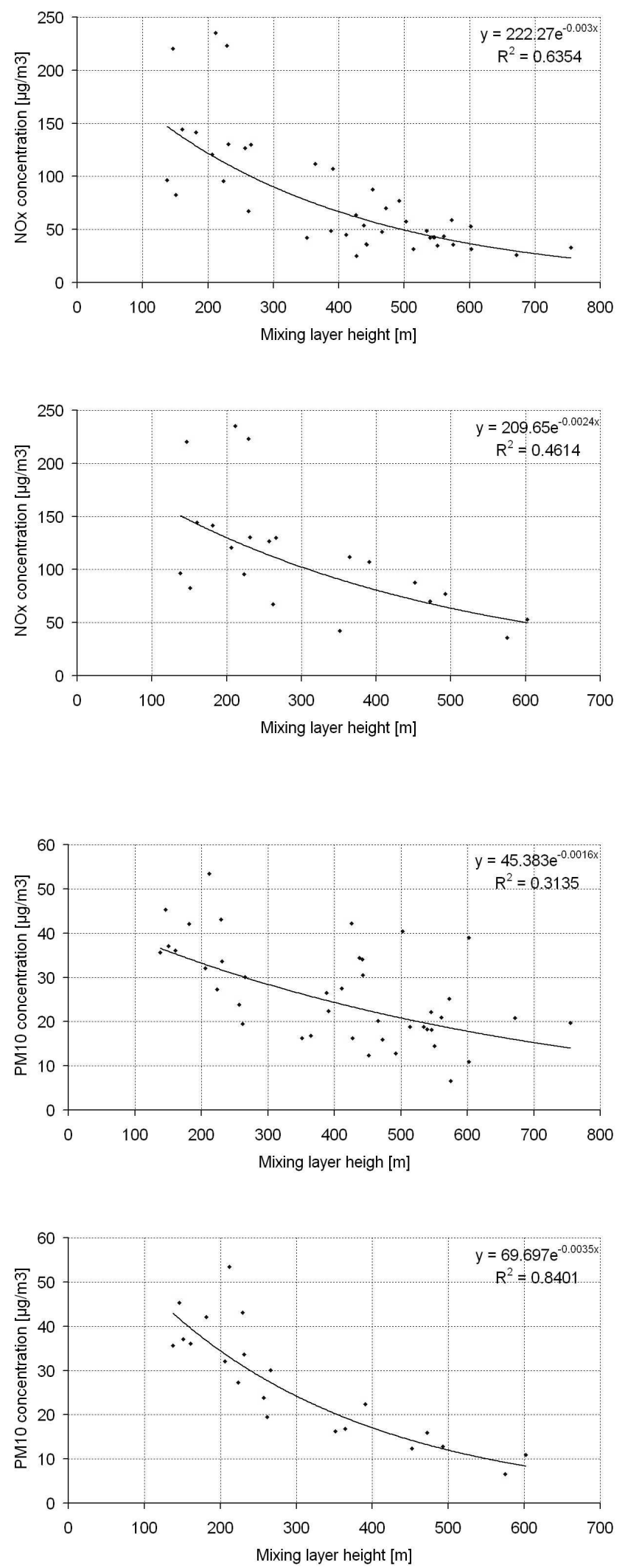

ternoon (more or less all days for less than five hours). For December 2003 the MLH from ceilometer measurements in Frankendorf was in good coincidence with the

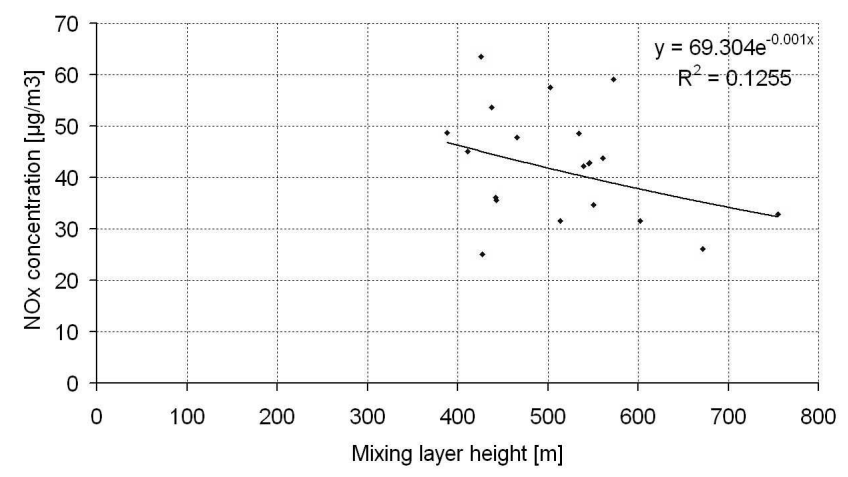

Figure 4: Seasonal variation of the square of the correlation coefficient $\mathrm{R}^{2}$ and parameters of exponential relationship for $\mathrm{NO}_{x}$ concentration with mixing layer height (MLH) from SODAR for the rural station outside Munich (Maisach), the urban stations inside Munich (Luise-Kiesselbach-Platz, Stachus, Lothstrasse, Moosach) and the urban background station in Munich Johanneskirchen: all data (top left), summer (top right) and winter (bottom).

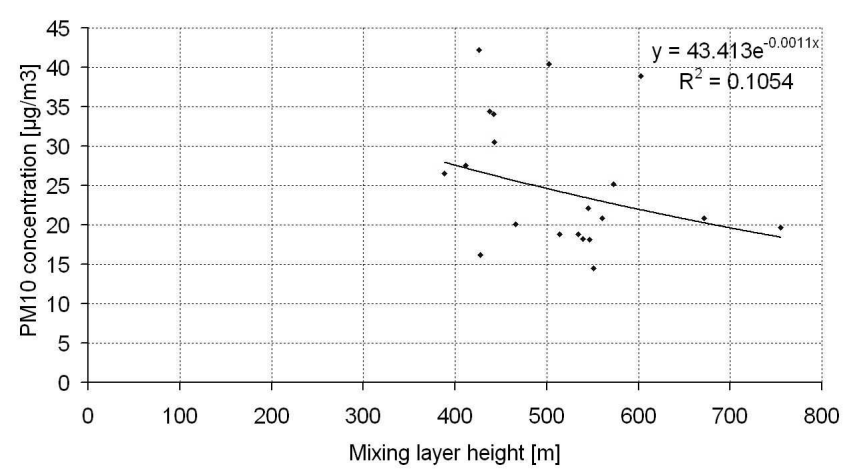

Figure 5: Seasonal variation of the square of the correlation coefficient $\mathrm{R}^{2}$ and parameters of exponential relationship for $\mathrm{PM}_{10}$ concentrations with mixing layer height (MLH) from SODAR for the rural stations outside Munich (Maisach, Frankendorf), the urban background station at roof-top (MIM) and the urban stations inside Munich (Luise-Kiesselbach-Platz, Stachus, Lothstrasse): all data (top left), summer (top right) and winter (bottom).
SODAR data as shown in EMEIS and SCHÄFER (2006). A typical rise of the MLH during a day with strong convection in the afternoon as well as a residual layer 
Table 1: Seasonal variation of the square of the correlation coefficient $\left(\mathrm{R}^{2}\right)$ and parameters for exponential fitting $\left(\mathrm{y}=\mathrm{a} \mathrm{e}^{b x}\right)$ of $\mathrm{NO}_{x}$ concentration dependence (y) from mixing layer height (x) in Hanover (urban background station) and Munich (all stations).

\begin{tabular}{|c|c|c|c|c|c|c|}
\hline & $\begin{array}{l}\text { Hanover } \\
\text { urban } \\
\text { background } \\
\text { station }\end{array}$ & $\begin{array}{l}\text { Hanover } \\
\text { urban } \\
\text { background } \\
\text { station }\end{array}$ & $\begin{array}{l}\text { Hanover } \\
\text { urban } \\
\text { background } \\
\text { station }\end{array}$ & $\begin{array}{l}\text { Munich } \\
\text { all } 6 \text { stations }\end{array}$ & $\begin{array}{l}\text { Munich } \\
\text { all } 6 \text { stations }\end{array}$ & $\begin{array}{l}\text { Munich } \\
\text { all } 6 \text { stations }\end{array}$ \\
\hline & Total & $\begin{array}{l}\text { Summer } \\
\text { 01 Aug - } \\
31 \text { Aug. } 2002\end{array}$ & $\begin{array}{l}\text { Winter } \\
06 \text { Oct. } 2001- \\
31 \text { Jan. } 2002 \\
\text { 01 Dec. } 2002- \\
28 \text { Febr. } 2003\end{array}$ & Total & $\begin{array}{l}\text { Summer } \\
10 \text { May - } \\
29 \text { May } \\
2003\end{array}$ & $\begin{array}{l}\text { Winter } \\
27 \text { Nov. - } \\
19 \text { Dec. } \\
2003\end{array}$ \\
\hline $\mathrm{a}$ & 60.3 & 41.5 & 60.1 & 222.3 & 69.3 & 209.7 \\
\hline $\mathrm{b}$ & -0.0023 & -0.0017 & -0.0021 & -0.003 & -0.001 & -0.0024 \\
\hline $\mathrm{R}^{2}$ & 0.46 & 0.30 & 0.41 & 0.64 & 0.13 & 0.46 \\
\hline
\end{tabular}

above the mixing layer during night and early morning hours can be seen from the ceilometer data together with the SODAR data. Also a good coincidence between the ceilometer MLH results and the temperature inversion from radiosonde and WTR data was found.

Further comparisons of the abovementioned remote sensing data from this experimental campaign with two lidars operated in the centre of the town and aircraft measurements are presented and discussed in WIEGNER et al. (2005). A major outcome from this study is that the MLH is nearly horizontally homogeneous over the area of Munich, which permits to use information from the SODAR and the ceilometer together although the instruments were about $50 \mathrm{~km}$ apart. This homogeneity is in contrast to other studies, e.g. for Nashville (ANGEVINE et al., 2003). During summer there is at both sites in the Munich area an uncertainty for high mixing layers in the order of $10 \%$ of the presented MLH data due to setting MLH at a maximum of $1200 \mathrm{~m}$.

\subsection{Data averaging for correlation studies}

Daily averages of MLH had to be determined for the Munich campaign, due to the fact that in the Munich area the $\mathrm{PM}_{10} / \mathrm{PM}_{2.5} / \mathrm{PM}_{1}$ data (Maisach, MIM in the city of Munich and Frankendorf) are available as daily averages only. Therefore 24-h-averages of $\mathrm{CO}$ and $\mathrm{NO}_{x}$ concentrations are calculated for the correlation studies, too.

Additionally, traffic emissions and MLH show comparable daily variations. They are low during the night and they rise during the day. This unphysical correlation which is due to human behaviour does not interest here. Consequently daily mean values of air pollutant concentrations and MLH are used for the investigations from both campaigns.

\subsection{Error estimates for the correlation analyses}

An estimation of the total error of the correlation values is necessary to demonstrate the reliability of the determined correlation coefficients. The concentrations of $\mathrm{NO}_{x}$ and $\mathrm{CO}$ are measured with a standard error in the order of $5 \%(\mathrm{~S} 1=0.05)$ and $\mathrm{PM}_{10}$ as well as $\mathrm{PM}_{2.5}$ with a standard error in the order of $15 \%(\mathrm{~S} 1=0.15)$. The determination of MLH from SODAR data has an error of about $10 \%(\mathrm{~S} 2=0.10)$ if MLH is within the detection range. Thus, the overall error of correlation between the concentrations and MLH can be estimated from the following equation

$$
\text { OverallStandardError }=1-(1-\mathrm{S} 1) *(1-\mathrm{S} 2)
$$

which is giving a value of $14.5 \%$ for $\mathrm{NO}_{x}$ and $\mathrm{CO}$ and of $23.5 \%$ for $\mathrm{PM}_{10}$ and $\mathrm{PM}_{2.5}$. Only such correlation coefficients between concentrations and MLH which are higher than this value are significant i.e. showing dependence between these data.

\section{Results}

Different fitting functions have been tried to describe the relation between pollution concentrations and MLH such as linear, hyperbolic, logarithmic, and polynomial functions. An exponential fitting is found to give the highest correlation coefficients for the dependence of the concentrations (y) on the MLH (x): $\mathrm{y}=\mathrm{a} \mathrm{e}^{b x}$ with negative values of $b$. This function has therefore been used throughout this study. We will concentrate on seasonal variations and differences between the different station types (street canyon, urban, urban background and rural). 
Table 2: Seasonal variation of the square of the correlation coefficient $\left(\mathrm{R}^{2}\right)$ and parameters for exponential fitting $\left(\mathrm{y}=\mathrm{a} \mathrm{e}^{b x}\right)$ of $\mathrm{PM}_{10}$ concentration (y) dependence from mixing layer height (x) in Hanover (urban background station) and Munich (all stations).

\begin{tabular}{|c|c|c|c|c|c|c|}
\hline & $\begin{array}{l}\text { Hanover } \\
\text { urban } \\
\text { background } \\
\text { station }\end{array}$ & $\begin{array}{l}\text { Hanover } \\
\text { urban } \\
\text { background } \\
\text { station }\end{array}$ & $\begin{array}{l}\text { Hanover } \\
\text { urban } \\
\text { background } \\
\text { station }\end{array}$ & $\begin{array}{l}\text { Munich } \\
\text { all } 6 \text { stations }\end{array}$ & $\begin{array}{l}\text { Munich } \\
\text { all } 6 \text { stations }\end{array}$ & $\begin{array}{l}\text { Munich } \\
\text { all } 6 \text { stations }\end{array}$ \\
\hline & Total & $\begin{array}{l}\text { Summer } \\
\text { 01 Aug - } \\
\text { 31 Aug. } 2002\end{array}$ & $\begin{array}{l}\text { Winter } \\
06 \text { Oct. } 2001- \\
31 \text { Jan. } 2002 \\
\text { 01 Dec. } 2002- \\
\text { 28 Febr. } 2003\end{array}$ & Total & $\begin{array}{l}\text { Summer } \\
10 \text { May - } \\
29 \text { May } \\
2003\end{array}$ & $\begin{array}{l}\text { Winter } \\
27 \text { Nov. - } \\
19 \text { Dec. } \\
2003\end{array}$ \\
\hline $\mathrm{a}$ & 50.2 & 79.9 & 47.9 & 45.4 & 43.4 & 69.70 \\
\hline $\mathrm{b}$ & -0.0016 & -0.0022 & -0.0015 & -0.0016 & -0.0011 & -0.0035 \\
\hline $\mathrm{R}^{2}$ & 0.16 & 0.23 & 0.17 & 0.31 & 0.11 & 0.84 \\
\hline
\end{tabular}

\subsection{Seasonal variations}

For the investigation of seasonal variations two smaller data subsets have been selected from the large Hanover data set on the basis of the analyses of the meteorological situation: the summer data set comprises the period 01-31 August 2002, and the winter data set the two periods 06 October 2001-31 January 2002 and 01 December 2002-28 February 2003. For Munich the data from May 2003 are considered as summer data, and the data from November and December 2003 as winter data.

The outcome of the correlation analyses with MLH using $\mathrm{NO}_{x}$ and $\mathrm{PM}_{10}$ concentration data for all data and for seasonal subsets of these data for the urban background station in Hanover and for six Munich stations comprising urban, urban background and rural conditions are shown in Figures 2 to 5 and in Tables 1 and 2. It turns out that in both towns all-year correlations for $\mathrm{NO}_{x}$ are higher (square of the correlation coefficient $\mathrm{R}^{2}=0.46$ and 0.64) than for $\mathrm{PM}_{10}\left(\mathrm{R}^{2}=0.16\right.$ and 0.31 , i.e. this correlation is only significant for Munich). In winter $\mathrm{NO}_{x}$ correlations are higher $\left(\mathrm{R}^{2}=0.41\right.$ and 0.46$)$ than those in summer $\left(\mathrm{R}^{2}=0.30\right.$ and 0.13$)$ again for both towns. For the correlation with $\mathrm{PM}_{10}$ the seasonal variation is not that clear. In Hanover there is nearly no difference between summer $\left(\mathrm{R}^{2}=0.23\right)$ and winter $\left(\mathrm{R}^{2}=0.17\right)$ correlations which are both not significant whereas in Munich the winter correlation between $\mathrm{PM}_{10}$ and MLH is very high $\left(\mathrm{R}^{2}=0.84\right)$ while the summer correlation $\left(\mathrm{R}^{2}=0.11\right)$ is negligible.

When interpreting the winter results for Munich one has to take into account the special weather situation which dominated this measurement period. It was strongly influenced by two Foehn periods (30 November-04 December and 09-11 December) and only two low pressure systems from north-west. Maxi- mum MLH of less than $300 \mathrm{~m}$ have been reached frequently due to the prevailing Foehn and wind in the boundary layer was very weak. The strong Foehn winds blew above the mixing layer. On 09 and 10 December 2003 a somewhat higher MLH has been observed in the afternoon, on the latter day this happened due to the passage of a cold front. The MLH in the region of Munich during the winter campaign was thus much lower than during the summer campaign, and it was also considerably lower than the hibernal MLH in Hanover.

The investigation of the influence of emission source strengths on the correlation of air pollutants with MLH by selecting periods of certain week days (Monday until Thursday), Friday, Saturday and Sunday did not bring conclusive results, mainly due to the lower amount of data during days with lower emission level (Friday, Saturday and Sunday) which caused a higher statistical variance of data than at days with higher emissions.

\subsection{Spatial variations}

Stations of different kinds were available for this study: one street canyon station (HRV1) in Hanover, four urban stations in Munich (only three of them having $\mathrm{PM}_{10}$ measurements), one urban background (roof-top) station in Hanover (HRSW) and two of them in Munich (roof of the MIM and Johanniskirchen), and two rural stations west and east of Munich. The outcome of the correlations at these stations is presented in Figures 6 to 8 and in Tables 3 and 4.

\subsubsection{Spatial variations of gases to MLH correlations}

We had seen in Section 3.1 that about $46 \%$ of $\mathrm{NO}_{x}$ concentration variations at the urban background (roof-top) 
Table 3: Station-specific variations of the square of the correlation coefficient $\left(\mathrm{R}^{2}\right)$ and parameters for exponential fitting $\left(\mathrm{y}=\mathrm{a} \mathrm{e}^{b x}\right)$ of $\mathrm{NO}_{x}$ and $\mathrm{PM}_{10}$ concentration (y) dependence from mixing layer height (x) in Hanover and Munich at different sites during the whole measurement time.

\begin{tabular}{cccccccc}
\hline & $\begin{array}{l}\text { Hanover } \\
\text { Street- } \\
\text { canyon }\end{array}$ & $\begin{array}{l}\text { Hanover } \\
\text { Street- } \\
\text { canyon }\end{array}$ & $\begin{array}{l}\text { Munich } \\
\text { rural and urban } \\
\text { background } \\
\text { stations }\end{array}$ & $\begin{array}{l}\text { Munich } \\
\text { urban } \\
\text { stations }\end{array}$ & $\begin{array}{l}\text { Munich } \\
\text { rural } \\
\text { stations }\end{array}$ & $\begin{array}{l}\text { Munich } \\
\text { urban } \\
\text { background } \\
\text { station }\end{array}$ & $\begin{array}{l}\text { Munich } \\
\text { urban } \\
\text { stations }\end{array}$ \\
\hline & $\mathrm{NO}_{\mathrm{x}}$ & $\mathrm{PM}_{10}$ & $\mathrm{NO}_{\mathrm{x}}$ & $\mathrm{NO}_{\mathrm{x}}$ & $\mathrm{PM}_{10}$ & $\mathrm{PM}_{10}$ & $\mathrm{PM}_{10}$ \\
$\mathrm{a}$ & 153.5 & 71.7 & 224.5 & 226.1 & 24.9 & 42.1 & 61.2 \\
$\mathrm{~b}$ & -0.0006 & -0.0012 & -0.0045 & -0.0025 & -0.0009 & -0.0017 & -0.0018 \\
$\mathrm{R}^{2}$ & 0.02 & 0.16 & 0.66 & 0.62 & 0.10 & 0.26 & 0.41 \\
\hline
\end{tabular}
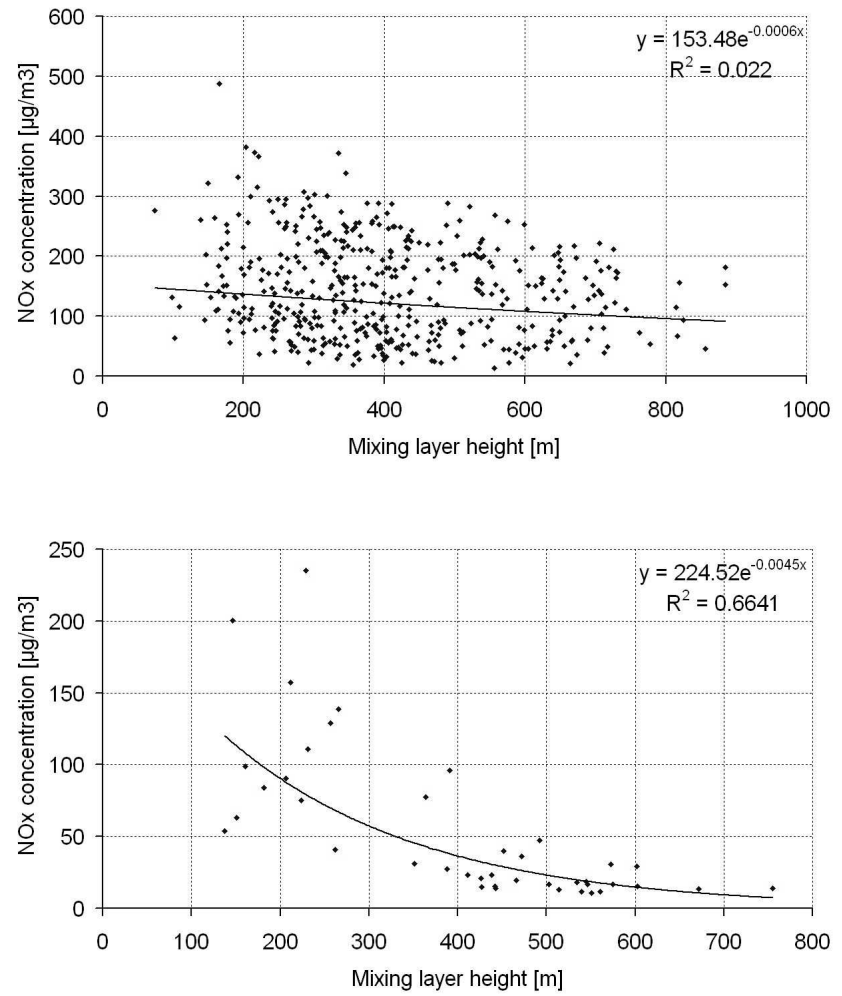

station in Hanover are related to the MLH. During days with high pollution levels in Hanover (e.g. on 13 December 2002 the daily mean concentration of $\mathrm{NO}_{x}$ was $78 \mu \mathrm{g} / \mathrm{m}^{3}$, the one of $\mathrm{PM}_{10}$ was $89 \mu \mathrm{g} / \mathrm{m}^{3}$ and the one of $\mathrm{PM}_{2.5}$ was $77 \mu \mathrm{g} / \mathrm{m}^{3}$ ) the mean MLH was relatively low $(380 \mathrm{~m})$. Otherwise during days with low pollution level (e.g. on 27 October 2002 daily mean concentration of $\mathrm{NO}_{x}$ was $7 \mu \mathrm{g} / \mathrm{m}^{3}$ ) the mean MLH was relatively high (735 m).

This considerable dependence disappears completely when moving down the $43 \mathrm{~m}$ from this background station to the bottom of the adjacent street canyon. The mean ground-level $\mathrm{NO}_{x}$ concentrations down there are

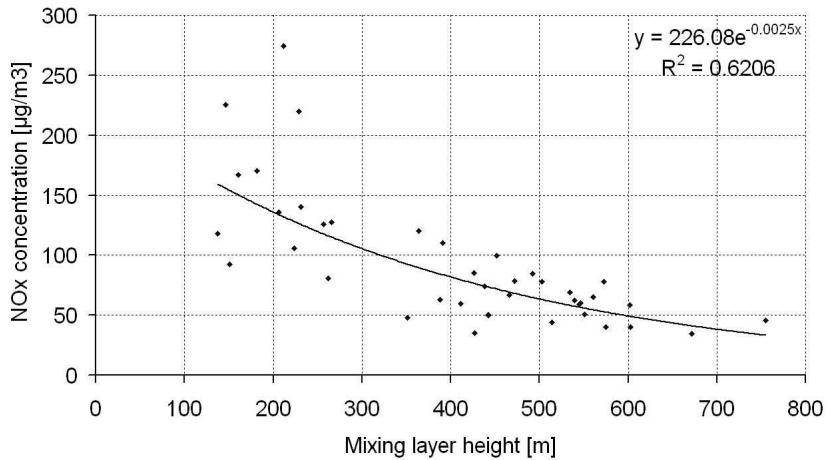

Figure 6: Square of the correlation coefficient $\mathrm{R}^{2}$ and parameters of exponential relationship for $\mathrm{NO}_{x}$ concentration with mixing layer height (MLH) from SODAR for an street-canyon station inside the street canyon Göttinger Strasse in Hanover (top left), for urban stations inside Munich (top right) and for the rural stations outside Munich (Maisach) and for the urban background station in Munich (Johanneskirchen) (bottom).

six times higher than at roof-top level, but $\mathrm{R}^{2}$ is only 0.02 (Figure 6a and Table 3). In Munich there are no such large differences in the all-year correlations between urban $\left(R^{2}=0.62\right.$, Figure $6 b$, Table 3$)$ and rural and urban background stations $\left(\mathrm{R}^{2}=0.66\right.$, Figure $6 \mathrm{c}$, Table 3). The latter result for $\mathrm{NO}_{x}$ is supported by the high correlation between $\mathrm{CO}$ and MLH at the urban stations $\left(\mathrm{R}^{2}=0.73\right.$, Figure 8c, Table 4$)$ in Munich.

\subsection{Spatial variations of particles to MLH correlations}

In contrast to the differences in the $\mathrm{NO}_{x}$ correlations between the background and the street canyon stations in 

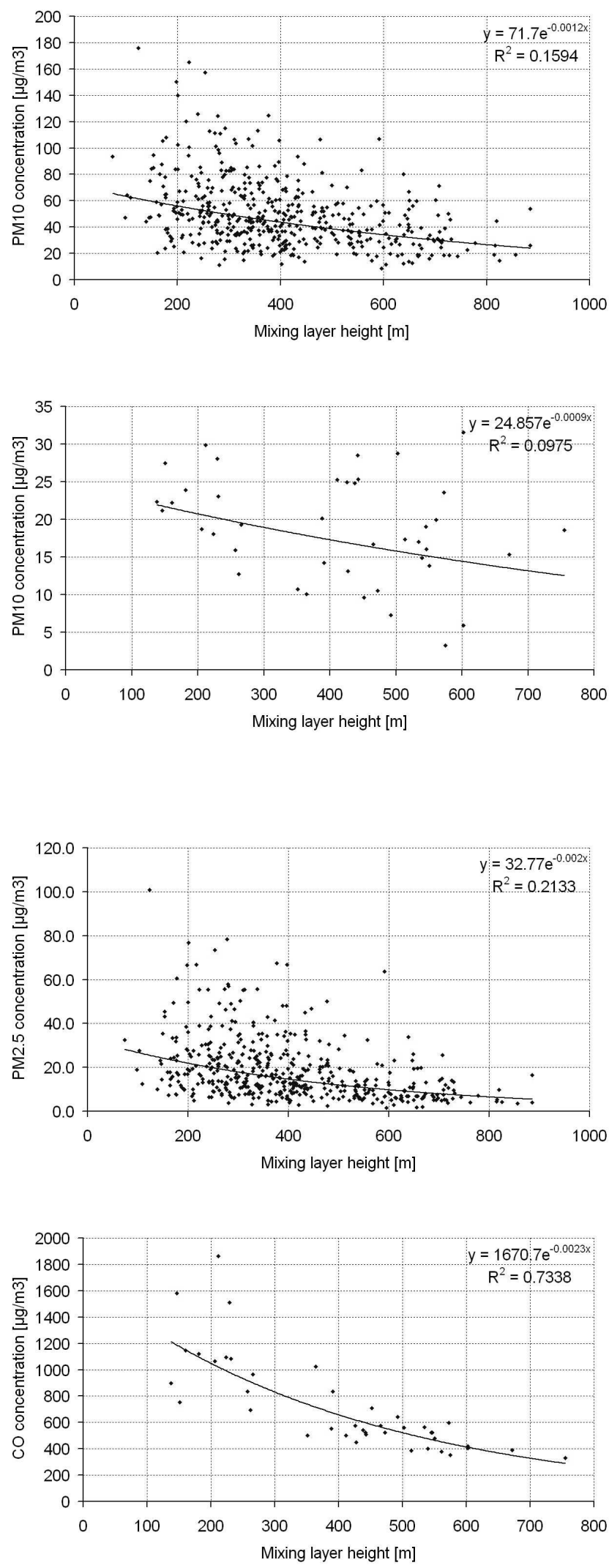

Hanover the correlations for $\mathrm{PM}_{10}$ with MLH do not differ much at these two stations. They are neither significant at the background station (for $\mathrm{PM}_{10}: \mathrm{R}^{2}=0.16$,

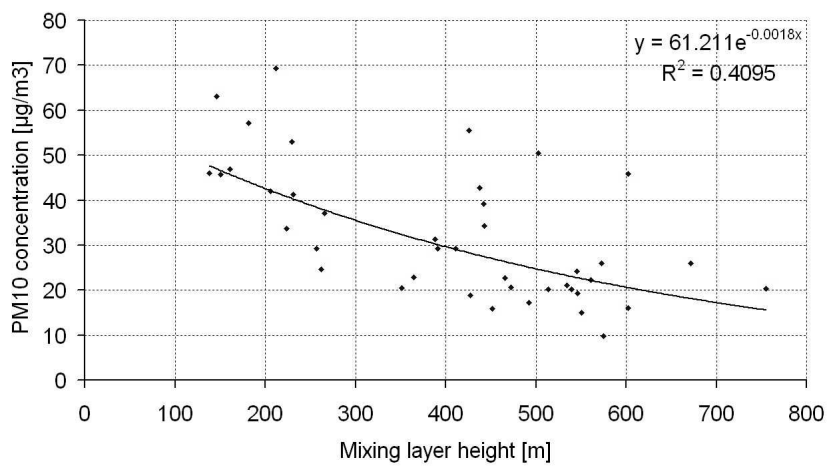

Figure 7: Square of the correlation coefficient $\mathrm{R}^{2}$ and parameters of exponential relationship for $\mathrm{PM}_{10}$ concentration with mixing layer height (MLH) from SODAR for an street-canyon station inside the street canyon Göttinger Strasse in Hanover (top left), urban stations inside Munich (top right) and rural stations outside Munich (bottom).

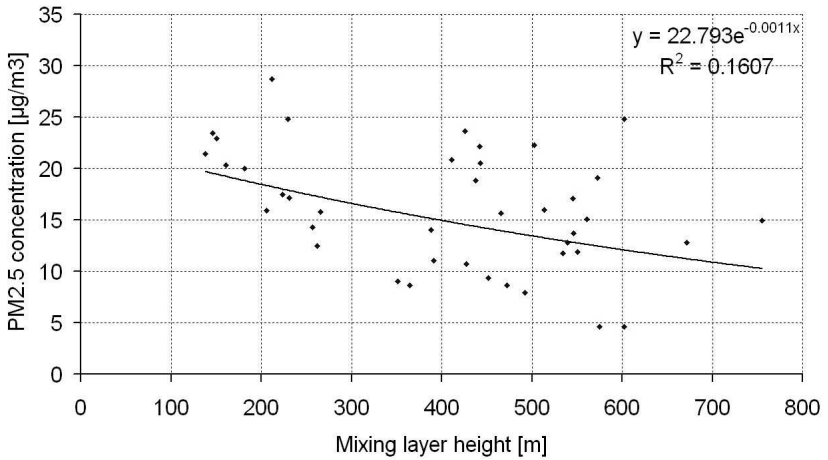

Figure 8: Square of the correlation coefficient $\mathrm{R}^{2}$ and parameters of exponential relationship for $\mathrm{PM}_{2.5}$ concentration with mixing layer height (MLH) from SODAR for the urban background station in Hanover (top left) and for the rural stations outside Munich (Maisach, Frankendorf) and the urban background station in $\mathrm{Mu}-$ nich at roof-top (MIM) (top right) as well as CO concentration with mixing layer height (MLH) from SODAR for urban stations in $\mathrm{Mu}$ nich (bottom).

Figure 3a, Table 2, for $\mathrm{PM}_{2.5}: \mathrm{R}^{2}=0.21$, Figure 8a, Table 4) nor at ground level inside the street canyon $\left(\mathrm{R}^{2}=\right.$ 0.16, Figure 7a, Table 3). Mean $\mathrm{PM}_{10}\left(\mathrm{PM}_{2.5}\right)$ concen- 
Table 4: Station-specific variations of the square of the correlation coefficient $\left(\mathrm{R}^{2}\right)$ and parameters for exponential fitting $\left(\mathrm{y}=\mathrm{a} \mathrm{e}^{b x}\right)$ of $\mathrm{PM}_{2.5}$ and $\mathrm{CO}$ concentration (y) dependence from mixing layer height $(\mathrm{x})$ in Hanover and Munich at different sites during the whole measurement time.

\begin{tabular}{cccc}
\hline & $\begin{array}{l}\text { Hanover urban } \\
\text { background station }\end{array}$ & $\begin{array}{l}\text { Munich rural and } \\
\text { urban background } \\
\text { stations }\end{array}$ & Munich urban stations \\
\hline & $\mathrm{PM}_{2.5}$ & $\mathrm{PM}_{2.5}$ & $\mathrm{CO}$ \\
$\mathrm{a}$ & 32.8 & 22.8 & 1670.7 \\
$\mathrm{~b}$ & -0.002 & -0.0011 & -0.0023 \\
$\mathrm{R}^{2}$ & 0.21 & 0.16 & 0.73 \\
\hline
\end{tabular}

trations at ground-level inside the street canyon are only 1.5 (1.25) times higher than the urban background values at this location in Hanover.

In Munich the opposite behaviour was found: larger spatial variations in the particle-MLH correlation than in the $\mathrm{NO}_{x}$-MLH correlations. The best correlation between $\mathrm{PM}_{10}$ concentrations and MLH is seen at the urban stations $\left(\mathrm{R}^{2}=0.41\right.$, Figure $7 \mathrm{~b}$, Table 3$)$, less good correlations are observed at the background station $\left(\mathrm{R}^{2}=0.26\right.$, Table 3$)$, and negligible correlations appear at the two rural stations $\left(\mathrm{R}^{2}=0.10\right.$, Figure $7 \mathrm{c}$, Table 3$)$. The correlation between $\mathrm{PM}_{2.5}$ and MLH at the rural and urban background stations in and around Munich is about the same as the one for $\mathrm{PM}_{10}\left(\mathrm{R}^{2}=0.16\right.$, Figure $8 \mathrm{~b}$, Table 4$)$. The all-year correlations between particle concentrations and MLH at urban and urban background stations in Munich turn out considerably better than those at the street canyon and urban background stations in Hanover.

\section{Discussion}

It is quite easily understandable that the correlations to the MLH are very low and insignificant with air pollution measurements made at the bottom of street canyons. Here, the concentrations are determined primarily by the strength of the local emissions. The vertical diffusion inside the street canyons is not related to the overall structure and height of the mixing layer but probably more to wind speed and direction.

The main questions which arise from the results in this study are:

- Why are the correlations between $\mathrm{NO}_{x}$ and MLH usually (with the exception of the Munich foehn case) better than between particle concentrations and MLH?

- Why are the correlations between particle concentrations and MLH in rural areas much lower than in urban areas?
- Why are the correlations between particle concentrations and MLH larger in Munich than in Hanover?

The last question is probably the easiest one. The quite special winter foehn episode with its very high correlations dominates the results for Munich. If one only looks at the summer data this phenomenon disappears.

The answer to the first two questions is much more difficult. One clue to the first question could be that $\mathrm{NO}_{x}$ is primarily emitted near the surface. Particles (especially in summer) are also formed as secondary pollutants within air masses (gas-to-particle conversion) so that the dilution influence of the rising MLH is reduced. Also other studies (CHARRON and HARRISON, 2006) show that in urban areas the local $\mathrm{PM}_{10}$ concentrations are strongly influenced by background conditions.

The main explanation for the second question could be that the surface sources for emitted particles in towns are much larger than in rural areas causing differences in particle size distribution and chemical composition between rural und urban areas (KUHN et al., 2005). Therefore in urban areas the dilution effect dominates the correlation between particle concentrations and MLH. In rural areas, in the absence of advection and strong sources, there should be mainly formation and dissolution of particles within the air mass. This formation tends to be positively correlated to MLH because it is strongest during the day when MLH rises. Thus the influence of gas-to-particle conversion partly cancels out the influence of the dilution of near-surface particle emissions.

\section{Conclusions}

It can be concluded that the pollution at roof-top level in Hanover is - as expected for an urban background station - caused by meteorological and transport conditions mainly and not by the emission situation. Consequently, this roof-top level station seems to be representative for the urban boundary layer. This conclusion is in coincidence with findings from numerical simulations by TRUKENMÜLLER et al. (2004). Otherwise air quality inside street canyons is not really coupled with the boundary layer height except for those meteorological situations which are characterised by strong advection and vertical transport.

The evaluation for Munich is a good example for the fact that low MLH is strongly related to high concentrations of gases and particulates and vice versa in winter. Mainly during winter the MLH determines the concentration of air pollutants near the surface by about $50 \%$ in areas which are not influenced by strong emissions and during time periods without strong vertical mixing and advection. 
The correlation coefficients have no significant values during summer. This is partly caused by the lack of information about the MLH which is higher during summer than during winter normally. But it has to be taken into account that in summer there is considerable formation of secondary air pollutants thus disturbing the simple relation between air pollutant concentrations and MLH. The remaining influences upon air pollution in these cases are emissions, advection, vertical transports and deposition. Thus, further analyses for the interpretation of these data sets as chemistry and deposition studies are necessary.

All cases considered here show for all pollutants the best correlation for an exponential dependence of the concentrations on MLH. In case of perfect mixing of a pollutant the pure dilution effect due to a rising MLH should lead to a hyperbolic (one over MLH) dependence. This suggests the assumption that the boundary layer is not completely well mixed but - due to the continuous emission near the ground - the concentrations probably decrease with altitude within the boundary layer.

These findings about the role of MLH for air quality must be considered during the evaluation of emission models and inventories and it is essential for the validation of numerical local-scale and meso-scale chemistrytransport models.

\section{Acknowledgements}

The authors would like to thank the German Federal Ministry of Education and Research for funding part of this work with grant 07ATF12 (Entwicklung und Validierung von Instrumenten zur Umsetzung der europäischen Luftqualitätspolitik - VALIUM) in frame of the AFO 2000 program together with the partners during the measurement campaigns Michael SCHATZMAnN, Wolfgang J. Müller, Bernd Heits, Dirk HAASE and Wolf-Dieter DRUnKENMÖLle, Michael Köckritz and Candy MATUSE. The authors likewise thank the EC for funding of the project "Integrated Computational Assessment of Air Quality via Remote Observations Systems Network" (ICAROS NET, contract IST-2000-29264) and the partners from measurement campaigns Dimosthenis SARIGIANNIS, Peter KöPKe, Bernhard RAPPENGLÜCK, Selina Utzig, Andreas Rauch, Gabriel Peicu, Andreas Harbusch, Konrad Nitzinger and Peter RABL. Peter SuPPAN helped to focus the discussion of the results.

\section{References}

Angevine, W.M., A.B. White, C.J. SenfF, M. Trainer, R.M. BAntA, M.A. Ayoub, 2003: Urbanrural contrasts in mixing height and cloudiness over Nashville in 1999. - J. Geophys. Res. 108, 4092, DOI: 10.1029/2001JD001061
ARON, R., 1983: Mixing height - an inconsistent indicator of potential air pollution concentrations. - Atmos. Environ. 17, 2193-2197.

BEYRICH, F., 1997: Mixing height estimation from sodar data - a critical discussion. - Atmos. Environ. 31, 39413953.

Charron, A., R.M. HARrison, 2006: Investigations of particulate matter data monitored near a busy London highway. $2^{\text {nd }}$ conference Environment and Transport, including $15^{\text {th }}$ conference Transport and Air Pollution, 12-14 June 2006. Reims. Robert JOUMARD (Ed.). - Actes INRETS, Institut National de Recherche Sur les Transports et leur Securite, Bron cedex, France, Vol. 1, 255-262.

Dandou, E., E. Bosioli, M. Tombrou, N. Sifakis, D. PARONis, N. Soulakellis, D. SARIGIANNIS, 2002: The Importance of Mixing Height in Characterising Pollution Levels from Aerosol Optical Thickness Derived by Satellite. - Int. J. Water, Air and Soil Poll. Focus 2, 17-28.

EMEIS, S., K. SCHÄFER, 2006: Remote sensing methods to investigate boundary-layer structures relevant to air pollution in cities. - Bound-Layer Meteor. DOI: 10.1007/s10546-006-9068-2.

EMEIS, S., M. TÜRK, 2004: Frequency distributions of the mixing height over an urban area from sodar data. - Meteorol. Z. 13, 361-367.

Emeis, S., C. Münkel, S. Vogt, W. Müller, K. SCHÄFER, 2004: Determination of mixing-layer height. Atmos. Environ. 38, 273-286.

Kunn, T., S. Biswas, C. Sioutas, 2005: Diurnal and seasonal characteristics of particle volatility and chemical composition in the vicinity of a light-duty vehicle freeway. - Atmos. Environ. 39, 7154-7166.

Müller, W.J., B. Heits, M. SchatzManN, 2001: A Prototype Station for the Collection of Urban Meteorological Data. - In: Proceedings of the $8^{\text {th }}$ International Conference on Harmonisation within Atmospheric Modelling for Regulatory, Sofia, www.harmo.org/Conferences/Proceedings/_Sofia/ publishedSections/Pages326.pdf.

Nolte, T., W. Müller, B. Heits, K. Schäfer, W. Busch, R. Beyer, W.-D. Drunkenmölle, J. THARSEN, 2004: ValiData. Database and pre-analyses tool of the VALIUM project. - Niedersächsisches Landesamt für Ökologie, Hannover; Institut für Meteorologie und Klimaforschung, Forschungszentrum Karlsruhe, GarmischPartenkirchen. Available from the principal author.

Piringer, M., S. Joffre (EDS.), A. BAKLANOV, J. Burzynski, A. Christen, M. Deserti, K. DE RidDER, S. EMEIS, S. JofFre, A. KARPPinen, P. MESRAyer, D. Middleton, M. Piringer, M. Tombrou (Lead authors), 2005: The urban surface energy budget and mixing height in European cities: Data, models and challenges for urban meteorology and air quality. Final Report of Working Group 2 of COST-715 Action. - Demetra Publ., Bulgaria. 239 pp.

RAMPANELli, G., D. ZARDI, 2004: A method to determine the capping inversion of the convective boundary layer. - J. Appl. Meteor. 43, 925-933.

SARIGIANNIS, D.A., N. Soulakellis, K. SCHÄFER, M. TOMbrou, N.I. SifAKIS, D. Assimakopoulos, M. Lointier, A. DAnTou, M. SAisAna, 2002: ICAROS: 
An Integrated Computational Environment for the Assimilation of Environmental Data and Models for Urban and Regional Air Quality. - Int. J. Water, Air, and Soil Pollut.: Focus 2, 641-654.

SCHÄFER, K., G. Fömmel, H. HofFMAnN, S. BRIZ, W. JunkermanN, S. EMEIS, C. JAHN, S. LeIPOLD, A. Sedlmaier, A. Dinev, C. Reishofer, L. Windholz, N. Soula Kellis, N.I. SifAKIS, D. SARIGIANNIS, 2002: Three-Dimensional Ground-Based Measurements of Urban Air Quality to Evaluate Satellite Derived Interpretations for Urban Air Pollut. - Int. J. Water, Air, and Soil Pollut.: Focus 2, 91-102.

SCHÄFER, K., S. EMEIS, H. HOFFMANN, C. JAHN, W.J. Müller, B. Heits, D. HaAse, W.-D. DrunkenMÖlle, W. BÄChlin, H. SchlünZEN, B. Leitl, F. PASCHEKE, M. SCHATZMANN, 2005: Field measurements within a quarter of a city including a street canyon to produce a validation data set. - Int. J. Environ. and Pollut. 25, 201-216.
Seibert, P., F. Beyrich, S.-E. Gryning, S. Joffre, A. RASMUSSEN, P. TERCIER, 2000: Review and Intercomparison of Operational Methods for the Determination of the Mixing Height. - Atmos. Environ. 34, 1001-1027.

STEYN, D.G., M. BALDI, R.M. HofF, 1999: The detection of mixed layer depth and entrainment zone thickness from Lidar backscatter profiles. - J. Atmos. Oceanic Technol. 16, 953-959.

Trukenmüller A., D. Grawe, K.H. SChlünZEN, 2004: A model system for the assessment of ambient air quality conforming to EC directives. - Meteorol. Z. 13, 387-394.

Wiegner, M., S. Emeis, V. Freudenthaler, B. Heese, W. Junkermann, C. MÜnkel, K. SChäfer, M. SEEFEldNER, S. VoGt, 2006: Mixing Layer Height over Munich, Germany: Variability and comparisons of different methodologies. - J. Geophys. Res. Atmos. 111, D13201, Doi:10.1029/2005JD006593.

Zhang, J., S.T. RaO, 1999: The Role of Vertical Mixing in the Temporal Evolution of Ground-Level Ozone Concentrations. - J. Appl. Meteor. 38, 1674-1691. 